\title{
Pengaruh Leverage dan Capital Intensity pada Tax Avoidance dengan Proporsi Komisaris Independen sebagai Variabel Pemoderasi
}

\author{
Cyntia Habibah Sinaga ${ }^{1}$ \\ I Made Sadha Suardikha ${ }^{2}$
}

\author{
${ }^{1,2}$ Fakultas Ekonomi dan Bisnis Universitas Udayana (Unud), Bali, Indonesia \\ e-mail: cyntiasinaga45@gmail.com
}

\begin{abstract}
ABSTRAK
Penelitian ini bertujuan untuk memeroleh bukti empiris pengaruh leverage dan capital intensity pada tax avoidance dengan proporsi komisaris independen sebagai variabel pemoderasi. Populasi penelitian adalah perusahaan manufaktur yang terdaftar di Bursa Efek Indonesia tahun 2013-2017. Metode penentuan sampel yang digunakan adalah purposive sampling dan diperoleh 200 pengamatan. Teknik analisis data menggunakan analisis regresi linear berganda dan Moderated Regression Analysis (MRA). Hasil analisis menunjukkan bahwa leverage berpengaruh positif pada tax avoidance. Hal ini berarti semakin banyak utang yang digunakan perusahaan untuk membiayai asetnya, maka semakin tinggi tingkat penghindaran pajaknya. Capital intensity berpengaruh negatif pada tax avoidance. Hal ini berarti semakin banyak modal yang diinvestasikan perusahaan dalam bentuk aset tetap, maka semakin rendah tingkat penghindaran pajaknya. Proporsi komisaris independen tidak memoderasi pengaruh leverage dan capital intensity pada tax avoidance.
\end{abstract}

Kata kunci: leverage, capital intensity, komisaris independen, tax avoidance

\begin{abstract}
This study aims to obtain empirical evidence of the effect of leverage and capital intensity on tax avoidance with the proportion of independent commissioners as moderating variable. The research population is manufacturing companies listed on the Indonesia Stock Exchange in 20132017. The method of determining the sample used was purposive sampling and obtained 200 observations. Data analysis techniques using multiple linear regression analysis and Moderated Regression Analysis (MRA). The results of the analysis show that leverage has a positive effect on tax avoidance. This means that the more debt the company uses to finance assets, the higher level of tax avoidance. Capital intensity has a negative effect on tax avoidance. This means that the more capital invested by the company in the form of fixed assets, the lower level of tax avoidance. The proportion of independent commissioners does not moderate the effect of leverage and capital intensity on tax avoidance.
\end{abstract}

Keywords: leverage, capital intensity, independent commissioners, tax avoidance

\section{PENDAHULUAN}

Penerimaan pajak di Indonesia telah dirancang sedemikian rupa agar mencapai target yang diharapkan sesuai dengan Anggaran Pendapatan dan Belanja Negara (APBN). Tabel 1 menyajikan data mengenai target dan realisasi penerimaan pajak tahun 2013-2017. 
Tabel 1.

Target dan Realisasi Penerimaan Pajak Tahun 2013 - 2017 (dalam Triliun Rupiah)

\begin{tabular}{lccccc}
\hline & 2013 & 2014 & 2015 & 2016 & 2017 \\
\hline Target & $1.148,4$ & $1.246,1$ & $1.489,3$ & $1.539,2$ & $1.450,9$ \\
Realisasi & $1.077,3$ & $1.146,9$ & $1.240,4$ & $1.284,8$ & $1.339,8$ \\
Persentase & 93,8 & 92,0 & 83,3 & 83,5 & 92,3 \\
\hline Sumber: www.kemenkeu.go.id, 2018 & & & &
\end{tabular}

Berdasarkan Tabel 1 dapat dijelaskan bahwa realisasi penerimaan pajak di Indonesia mengalami peningkatan dari tahun 2013-2017, namun realisasi penerimaan pajak ini masih belum sesuai dengan target yang diharapkan. Hal ini membuktikan bahwa realisasi penerimaan pajak di Indonesia masih belum optimal. Salah satu penyebab tidak tercapainya target pajak ini adalah karena adanya tindakan pengelolaan beban pajak oleh perusahaan. Tindakan pengelolaan beban pajak merupakan tindakan yang dilakukan akibat adanya perbedaan kepentingan antara perusahaan dengan pemerintah (Lestari dan Putri, 2017). Pemerintah menginginkan pembayaran pajak yang tinggi agar dapat membiayai penyelenggaraan pemerintahan, sedangkan perusahaan menginginkan pembayaran pajak yang rendah karena pajak akan mengurangi pendapatan atau laba bersih perusahaan. Maka dari itu, wajib pajak cenderung untuk mengelola beban pajaknya agar seminimum mungkin baik secara legal maupun ilegal, dengan harapan dapat memeroleh laba yang maksimal (Darmawan dan Sukartha, 2014).

Cara meminimalkan beban pajak yang tidak melanggar undang-undang disebut dengan tax avoidance. Tax avoidance menurut Jacob (2014) adalah suatu tindakan untuk mengurangi beban pajak dengan hati-hati mengatur sedemikian rupa untuk mengambil keuntungan dari celah-celah dalam ketentuan pajak. 
Peraturan terkait pajak penghasilan di Indonesia diatur dalam Undang-Undang Nomor 36 Tahun 2008, dimana pada Pasal 6 Ayat 1 menjelaskan mengenai biaya yang dapat mengurangi penghasilan kena pajak. Perusahaan dapat mengambil keuntungan dari celah-celah dalam peraturan ini, misalnya dengan meningkatkan jumlah aset tetap perusahaan menggunakan utang sehingga akan menimbulkan beban penyusutan dan beban bunga yang dapat mengurangi besarnya penghasilan kena pajak perusahaan.

Salah satu indikasi perusahaan melakukan tax avoidance dapat dilihat pada rasio leverage. Leverage merupakan tingkat utang yang digunakan oleh perusahaan untuk membiayai aktivitas operasinya (Dharma dan Ardiana, 2016). Menurut Wijayanti dan Lely (2017), besarnya tingkat utang dapat menimbulkan beban bunga bagi perusahaan. Beban bunga yang timbul akibat penggunaan utang merupakan beban yang dapat mengurangi laba sebelum pajak, sehingga mengurangi beban pajak yang harus dibayar oleh perusahaan. Hal ini menyebabkan kewajiban pajak perusahaan berkurang dan dapat digolongkan sebagai tindakan tax avoidance (Dewi dan Noviari 2017).

Penelitian terkait pengaruh leverage pada tax avoidance telah dilakukan oleh beberapa peneliti. Hasil penelitian Darmawan dan Sukartha (2014) menunjukkan bahwa leverage tidak berpengaruh pada tax avoidance. Namun, hasil penelitian Lestari dan Putri (2017) serta Salaudeen (2017) menunjukkan bahwa leverage berpengaruh negatif pada tax avoidance, sedangkan hasil penelitian Praditasari dan Setiawan (2017) serta Wijayanti dan Lely (2017) menunjukkan bahwa leverage berpengaruh positif pada tax avoidance. 
Selain leverage, variabel lain yang dapat memengaruhi tax avoidance adalah capital intensity atau rasio intensitas modal. Capital intensity ratio merupakan rasio yang menunjukkan seberapa banyak modal perusahaan yang diinvestasikan dalam bentuk aset tetap (Muzakki dan Darsono, 2015). Menurut Delgado et al (2014), aset tetap yang dimiliki perusahaan dapat mengurangi pajak yang disebabkan oleh penyusutan aset tetap perusahaan setiap tahunnya. Semakin banyak investasi perusahaan pada aset tetap, maka semakin banyak perusahaan akan menanggung beban penyusutan (Andhari dan Sukartha, 2017). Beban penyusutan ini dapat menambah beban perusahaan yang dapat mengurangi laba sebelum pajak. Semakin rendah laba sebelum pajak, maka semakin rendah beban pajak perusahaan.

Penelitian terkait pengaruh capital intensity pada tax avoidance telah dilakukan oleh Muzakki dan Darsono (2015) serta Budianti dan Curry (2018) yang menunjukkan bahwa capital intensity berpengaruh negatif pada tax avoidance, dan Dharma dan Noviari (2017) serta Anindyka dkk (2018) yang menunjukkan bahwa capital intensity berpengaruh positif pada tax avoidance. Hal ini berbeda dengan hasil penelitian yang dilakukan oleh Jingga dan Lina (2017) serta Irianto et al (2017) menunjukkan hasil bahwa capital intensity tidak berpengaruh pada tax avoidance.

Permasalahan mengenai praktik tax avoidance di Indonesia masih menarik untuk diteliti, karena tax avoidance dapat meminimalkan beban pajak sehingga menguntungkan perusahaan tanpa melanggar peraturan perpajakan yang berlaku. Alasan yang mendasari penggunaan variabel leverage dan capital intensity 
sebagai variabel bebas dalam penelitian ini adalah karena leverage dan capital intensity sama-sama menggambarkan kebijakan yang diambil perusahaan yang dapat menimbulkan biaya untuk mengurangi besarnya beban pajak perusahaan, sehingga berpengaruh pada tax avoidance.

Berdasarkan uraian hasil penelitian terdahulu yang telah disebutkan di atas menunjukkan hasil yang tidak konsisten mengenai pengaruh leverage dan capital intensity pada tax avoidance, sehingga pengaruh variabel-variabel tersebut perlu diteliti kembali dengan menambahkan variabel proporsi komisaris independen sebagai pemoderasi. Alasan penggunaan proporsi komisaris independen sebagai variabel pemoderasi adalah karena banyaknya komisaris independen dalam suatu perusahaan mampu mengawasi perilaku oportunistik manajer yang mungkin saja terjadi. Misalnya, mengakui pendapatan yang berasal dari penjualan sebagai utang agar dapat memanfaatkan beban bunga yang timbul untuk mengurangi laba perusahaan sehingga dapat menekan beban pajak perusahaan, atau membeli aset tetap secara fiktif agar memeroleh biaya penyusutan atas aset tetap untuk mengurangi laba perusahaan yang berdampak pada berkurangnya beban pajak perusahaan.

Keberadaan komisaris indepeden dalam suatu perusahaan dapat memiliki dampak positif pada kinerja perusahaan dan nilai perusahaan (Zhou, 2011). Penelitian yang dilakukan Wijayanti dan Lely (2017) menunjukkan bahwa semakin meningkatnya jumlah komisaris independen menandakan semakin besar pengaruh komisaris independen untuk mengawasi kinerja manajemen, sehingga 
manajemen lebih berhati-hati dalam mengambil keputusan dan meminimalisir terjadinya tax avoidance.

Trade-off theory menjelaskan bahwa penggunaan utang sebagai sumber pendanaan keuangan perusahaan dapat memberi manfaat berupa beban bunga sebagai pengurang beban pajak. Trade-off theory menerangkan bahwa pencapaian struktur modal yang optimal terjadi apabila manfaat dan pengorbanan yang timbul akibat penggunaan utang adalah seimbang (Hackbarth dan Zhou, 2018). Kebijakan perusahaan terkait dengan keputusan pendanaan dapat digambarkan melalui rasio leverage yang dimiliki perusahaan (Arianandini dan Ramantha, 2018). Semakin tinggi rasio leverage, maka jumlah utang perusahaan dan beban bunga yang timbul dari utang tersebut pun semakin tinggi. Beban bunga yang timbul akibat penggunaan utang dapat mengurangi laba sebelum pajak perusahaan, sehingga penggunaan utang memberikan hubungan positif pada aktivitas tax avoidance suatu perusahaan (Arianandini dan Ramantha, 2018). Hal ini sejalan dengan penelitian Rachmitasari (2015) yang memeroleh hasil bahwa leverage berpengaruh positif pada tax avoidance. Berdasarkan telaah teori dan hasil penelitian terdahulu, maka dirumuskan hipotesis penelitian sebagai berikut.

$\mathrm{H}_{1}$ : Leverage berpengaruh positif pada tax avoidance.

Comanor dan Wilson (1967) mengemukakan bahwa capital intensity menunjukkan efisiensi penggunaan modal yang telah ditanamkan perusahaan dalam bentuk aset tetap, sehingga capital intensity merupakan salah satu informasi yang penting bagi investor. Berdasarkan teori keagenan, terdapat perbedaan kepentingan antara pemilik saham (prinsipal) dengan manajemen (agen) 
(Jensen dan Meckling, 1976). Kepentingan manajemen adalah memeroleh peningkatan kompensasi melalui laba yang tinggi, sedangkan pemegang saham ingin mengurangi biaya pajak melalui laba yang rendah. Hal ini dapat diatasi dengan memanfaatkan beban penyusutan aset tetap untuk menekan beban pajak perusahaan.

Manajer dapat menginvestasikan modal perusahaan ke dalam bentuk aset tetap untuk memanfaatkan beban penyusutan sebagai pengurang beban pajak. Pemanfaatan beban penyusutan aset tetap sebagai pengurang beban pajak akan berdampak pada terpenuhinya kepentingan manajemen yang menginginkan peningkatan laba perusahaan, begitu pula kepentingan pemegang saham yang menginginkan biaya pajak yang rendah (Wiguna dan Jati, 2017). Semakin tinggi capital intensity suatu perusahaan maka tax avoidance perusahaan pun semakin tinggi (Anindyka dkk, 2018). Hal ini sejalan dengan penelitian Dharma dan Noviari (2017) bahwa capital intensity terbukti memiliki pengaruh positif pada tax avoidance. Berdasarkan telaah teori dan hasil penelitian terdahulu, maka dirumuskan hipotesis penelitian sebagai berikut.

$\mathrm{H}_{2}$ : Capital intensity berpengaruh positif pada tax avoidance.

Teori keagenan menjelaskan bahwa masalah keagenan timbul ketika kepengurusan perusahaan terpisah dari kepemilikannya. Adanya pemisahan kepengurusan perusahaan antara pemilik (prinsipal/investor) dengan pengendali (agen/manajer), membuat komisaris independen sebagai pihak yang tidak terafiliasi dengan pemegang saham maupun anggota direksi dan dewan komisaris untuk melakukan pengawasan yang ketat terhadap manajemen agar meminimalisir 
masalah keagenan (Diantari dan Ulupui, 2016). Pengawasan yang ketat dapat berpengaruh pada sikap manajemen perusahaan, karena meningkatnya pengawasan dalam perusahaan menyebabkan manajemen cenderung lebih berhatihati untuk mengambil setiap keputusan, termasuk keputusan yang terkait dengan pembayaran pajak (Dewi dan Noviari, 2017).

Perusahaan dapat mengurangi pembayaran pajaknya melalui penggunaan utang sebagai pendanaan aktivitas operasinya, karena penggunaan utang ini akan menimbulkan beban bunga yang menjadi pengurang laba sebelum pajak perusahaan sehingga dapat menekan beban pajak perusahaan. Hal ini dapat digunakan oleh perusahaan sebagai salah satu upaya tax avoidance, sehingga kehadiran komisaris independen diharapkan mampu meminimalisir perilaku oportunistik manajer yang mungkin dapat terjadi (Asri dan Suardana, 2016). Hal ini sejalan dengan penelitian Wijayanti dan Lely (2017) yang memeroleh hasil bahwa proporsi komisaris independen berpengaruh negatif pada tax avoidance. Berdasarkan telaah teori dan hasil penelitian terdahulu, maka dirumuskan hipotesis penelitian sebagai berikut.

$\mathrm{H}_{3}$ : Proporsi komisaris independen memperlemah pengaruh leverage pada tax avoidance.

Teori keagenan menjelaskan bahwa agency cost dapat digunakan untuk mengurangi konflik keagenan yaitu dengan menerapkan corporate governance untuk memastikan bahwa agen bertindak sesuai dengan keinginan prinsipal. Ariawan dan Setiawan (2017) mengemukakan bahwa komisaris independen termasuk ke dalam mekanisme corporate governance yang berfungsi untuk mengawasi kinerja dan mengontrol pengelolaan perusahaan. Semakin banyak 
proporsi komisaris independen maka pengawasan terhadap kinerja manajemen perusahaan terkait pelaporan beban pajak perusahaan secara wajar pun semakin meningkat, sehingga upaya tax avoidance yang dilakukan perusahaan dengan memanfaatkan penggunaan aset tetap dapat diminimalisir dengan adanya dewan komisaris independen. Hal ini sejalan dengan penelitian Maharani dan Suardana (2014) yang memeroleh hasil bahwa proporsi komisaris independen berpengaruh negatif pada tax avoidance. Berdasarkan telaah teori dan hasil penelitian terdahulu, maka dirumuskan hipotesis penelitian sebagai berikut.

$\mathrm{H}_{4}$ : Proporsi komisaris independen memperlemah pengaruh capital intensity pada tax avoidance.

\section{METODE PENELITIAN}

Penelitian dilakukan pada perusahaan manufaktur yang terdaftar di Bursa Efek Indonesia (BEI) tahun 2013-2017. Alasan yang mendasari melakukan penelitian pada perusahaan manufaktur yang terdaftar di BEI, yaitu: (1) perusahaan manufaktur merupakan perusahaan dengan jumlah aset tetap yang lebih besar jika dibandingkan perusahaan di bidang lainnya, sehingga kebijakan akuntansi mengenai penyusutan aset tetap dapat menggambarkan efek kebijakan perpajakan wajib pajak badan secara signifikan (Hartadinata dan Tjaraka, 2013); dan (2) perusahaan manufaktur merupakan perusahaan yang aktivitas usahanya secara keseluruhan terkait dengan perpajakan, mulai dari pembelian bahan baku, pengolahan bahan baku menjadi barang jadi maupun barang setengah jadi hingga proses menjual kembali (Mulyani dkk., 2014). Periode yang dipilih dalam penelitian ini selama 5 tahun berturut-turut dimulai dari tahun 2013-2017, karena 
periode penelitian ini merupakan periode penelitian terbaru dan periode penelitian selama 5 tahun cukup mewakilkan laporan keuangan dan catatan atas laporan keuangan secara konsisten.

Objek penelitian adalah tax avoidance yang dijelaskan oleh leverage, capital intensity, interaksi antara leverage dengan proporsi komisaris independen, dan interaksi antara capital intensity dengan proporsi komisaris independen.

Tax avoidance diukur menggunakan proksi Cash Effective Tax Rate (CETR). Alasan menggunakan CETR untuk mengukur ada atau tidaknya tax avoidance adalah karena CETR mengukur secara langsung arus kas keluar yang digunakan untuk perpajakan dibagi dengan laba sebelum pajak (Park, 2018). CETR mampu menggambarkan semua aktivitas tax avoidance yang mengurangi pembayaan pajak kepada otoritas perpajakan (Cahyanti dkk, 2017). Nilai CETR berkisar lebih dari 0 dan kurang dari 1, sehingga hanya perusahaan yang memiliki nilai CETR < 1 yang digunakan sebagai sampel agar tidak menimbulkan masalah dalam estimasi model (Gupta dan Newberry, 1997). CETR dalam penelitian ini akan dihitung berdasarkan rumus dalam penelitian Hanlon dan Heitzman (2010).

$$
\text { CETR }=\frac{\text { Pembayaran Pajak Penghasilan }}{\text { Laba Sebelum Pajak }}
$$

Leverage adalah jumlah utang yang digunakan untuk membiayai atau membeli aset-aset perusahaan (Annisa, 2017). Penelitian ini menggunakan proksi Debt to Asset Ratio (DAR) untuk mengukur leverage yang menggambarkan proporsi total liabilitas perusahaan terhadap total aset yang dimiliki perusahaan. Alasan menggunakan proksi DAR untuk mengukur leverage adalah karena DAR mampu menggambarkan keputusan pendanaan yang dilakukan oleh perusahaan 
(Darmawan dan Sukartha 2014). Semakin besar rasio DAR menunjukkan bahwa semakin besar jumlah utang yang digunakan oleh perusahaan sebagai sumber pendanaan untuk membiayai asetnya, begitu juga sebaliknya. Adapun rumus dari Debt to Asset Ratio (DAR) adalah sebagai berikut:

$$
\mathrm{DAR}=\frac{\text { Total Liabilitas }}{\text { Total Aset }} \times 100 \%
$$

Capital intensity menunjukkan efisiensi penggunaan modal yang telah ditanamkan perusahaan dalam bentuk aset tetap. Proksi dari capital intensity pada penelitian ini adalah rasio intensitas aset tetap. Rasio intensitas aset tetap merupakan rasio antara fixed asset terhadap total aset. Rasio ini digunakan untuk mengukur seberapa banyak aktiva tetap yang digunakan dalam kegiatan perusahaan (Reminda, 2017). Rumus capital intensity menurut Rodriguez dan Arias (2012), yaitu:

$$
\text { CAPINT }=\frac{\text { Aset Tetap }}{\text { Total Aset }}
$$

Komisaris independen merupakan seseorang tidak terafiliasi dalam segala hal dengan pemegang saham pengendali, direksi atau dewan komisaris, serta tidak menduduki jabatan sebagai direktur sebuah perusahaan yang berkaitan dengan perusahaan pemilik (Zemzem dan Ftouhi, 2013). Komisaris independen ditunjuk semata-mata karena pertimbangan profesionalisme untuk kepentingan perusahaan (Murni et al, 2016). Kehadiran komisaris independen mampu meningkatkan pengawasan secara professional terhadap kinerja para manajemen dan perilaku tax avoidance dalam perusahaan (Minnick dan Noga, 2010). Proporsi komisaris independen dihitung dengan membagi total komisaris independen dengan total 
anggota dewan komisaris (Wijayanti dan Lely, 2017). Rumus proporsi komisaris independen adalah sebagai berikut:

$$
\text { PROPKOMIN }=\frac{\text { Total Komisaris Independen }}{\text { Total Anggota Dewan Komisaris }}
$$

Populasi penelitian adalah perusahaan yang tergolong ke dalam sektor manufaktur yang terdaftar di Bursa Efek Indonesia (BEI) tahun 2013-2017. Sampel dalam penelitan ditentukan menggunakan metode nonprobability sampling dengan teknik purposive sampling, menggunakan kriteria-kriteria sebagai berikut: (1) perusahaan yang mempublikasikan annual report untuk periode yang berakhir pada tanggal 31 Desember, tidak mengalami kerugian selama periode pengamatan, dan tidak menerima pengembalian pajak; (2) perusahaan yang menggunakan mata uang rupiah sebagai mata uang pelaporan di laporan keuangan tahunan; dan (3) perusahaan yang memiliki nilai CETR $<1$.

Teknik analisis data yang digunakan adalah analisis regresi linear berganda dan uji MRA (Moderated Regression Analysis) dengan melakukan uji asumsi klasik terlebih dahulu agar data penelitian memenuhi syarat BLUE (Best Linear Unbiased Estimation) menggunakan program SPSS (Statistical Package for Social Science), setelah itu melakukan uji kelayakan model (uji F), uji koefisien determinasi $\left(\mathrm{R}^{2}\right)$, dan uji hipotesis (uji t). Analisis regresi linear berganda digunakan untuk menguji $\mathrm{H}_{1}$ dan $\mathrm{H}_{2}$, yaitu pengaruh leverage dan capital intensity pada tax avoidance. Model persamaan regresi linear berganda yang dibentuk pada penelitian ini adalah sebagai berikut.

$$
\mathrm{Y}=\alpha+\beta_{1} \mathrm{X}_{1}+\beta_{2} \mathrm{X}_{2}+\mathrm{e}
$$


Uji MRA digunakan untuk menguji $\mathrm{H}_{3}$ dan $\mathrm{H}_{4}$, yaitu kemampuan proporsi komisaris independen dalam memoderasi pengaruh leverage dan capital intensity pada tax avoidance. Model persamaan MRA yang dibentuk pada penelitian ini adalah sebagai berikut.

$$
\mathrm{Y}=\alpha+\beta_{1} \mathrm{X}_{1}+\beta_{2} \mathrm{X}_{2}+\beta_{3} \mathrm{X}_{3}+\beta_{4} \mathrm{X}_{1} \mathrm{X}_{3}+\beta_{5} \mathrm{X}_{2} \mathrm{X}_{3}+\mathrm{e}
$$

Keterangan :

$\mathrm{Y} \quad=$ Tax avoidance

$\mathrm{X}_{1} \quad=$ Leverage

$\mathrm{X}_{2} \quad=$ Capital intensity

$\mathrm{X}_{3} \quad=$ Proporsi komisaris independen

$\mathrm{X}_{1} \mathrm{X}_{3}=$ Interaksi antara leverage dengan proporsi komisaris independen

$\mathrm{X}_{2} \mathrm{X}_{3}=$ Interaksi antara capital intensity dengan proporsi komisaris independen

$\alpha \quad=$ Konstanta

$\beta_{1-} \beta_{5}=$ Koefisien regresi (nilai peningkatan maupun penurunan)

e $\quad=$ error

Ghozali (2016: 214) mengklasifikasikan variabel moderasi menjadi 4 jenis, yaitu prediktor moderator (moderasi sebagai prediktor), homologizer moderator (moderasi potensial), quasi moderator (moderasi semu), dan pure moderator (moderasi murni).

\section{HASIL DAN PEMBAHASAN}

Statistik deskriptif digunakan untuk mendeskripsikan variabel-variabel dalam penelitian ini yaitu tax avoidance, leverage, capital intensity, dan proporsi komisaris independen. Pengukuran yang digunakan dalam penelitian ini adalah nilai minimum, nilai maksimum, nilai rata-rata dan standar deviasi. Hasil statistik deskriptif dapat dilihat pada Tabel 2. 
Tabel 2.

Hasil Statistik Deskriptif

\begin{tabular}{lccccc}
\hline & $\mathrm{N}$ & Minimum & Maximum & Mean & Std. Deviation \\
\hline Tax Avoidance $(\mathrm{Y})$ & 200 & 0,0075 & 0,6579 & 0,2799 & 0,1026 \\
Leverage $\left(\mathrm{X}_{1}\right)$ & 200 & 0,0715 & 0,7518 & 0,3710 & 0,1647 \\
Capital Intensity $\left(\mathrm{X}_{2}\right)$ & 200 & 0,0671 & 0,7966 & 0,3331 & 0,1573 \\
Proporsi Komisaris & 200 & 0,2000 & 0,8000 & 0,3923 & 0,1009 \\
Independen (X) & & & & & \\
\hline Sumber: Data diolah, 2018 & & & & &
\end{tabular}

Berdasarkan Tabel 2 dapat diketahui nilai minimum, nilai maksimum, nilai rata-rata, dan standar deviasi dari masing-masing variabel penelitian. Variabel tax avoidance memiliki nilai minimum sebesar 0,0075 pada PT. Intanwijaya Internasional Tbk (INCI) tahun 2013 dan nilai maksimum sebesar 0,6579 pada PT. Ricky Putra Globalindo Tbk (RICY) tahun 2013. Nilai rata-rata variabel tax avoidance sebesar 0,2799 menunjukkan bahwa rata-rata tax avoidance pada perusahaan sampel sebesar 27,99 persen. Nilai standar deviasi variabel tax avoidance sebesar 0,1026 menunjukkan bahwa terjadi perbedaan nilai variabel tax avoidance yang diteliti terhadap nilai rata-ratanya sebesar 10,26 persen.

Variabel leverage memiliki nilai minimum sebesar 0,0715 pada PT. Semen Baturaja Tbk (SMBR) tahun 2014 dan nilai maksimum sebesar 0,7518 pada PT. Multi Bintang Indonesia Tbk (MLBI) tahun 2014. Nilai rata-rata variabel leverage sebesar 0,3710 mempunyai arti bahwa rata-rata tingkat utang yang digunakan oleh perusahaan sampel dalam membiayai asetnya sebesar 37,10 persen. Nilai standar deviasi variabel leverage sebesar 0,1647 menunjukkan bahwa terjadi perbedaan nilai variabel leverage yang diteliti terhadap nilai rata-ratanya sebesar 16,47 persen.

Variabel capital intensity memiliki nilai minimum sebesar 0,0671 pada PT. Delta Djakarta Tbk (DLTA) tahun 2017 dan nilai maksimum sebesar 0,7966 pada 
PT. Semen Baturaja Tbk (SMBR) tahun 2016. Nilai rata-rata variabel capital intensity sebesar 0,3331 mempunyai arti bahwa rata-rata total aset tetap pada perusahaan sampel sebesar 33,31 persen dari total asetnya. Nilai standar deviasi variabel capital intensity sebesar 0,1573 menunjukkan bahwa terjadi perbedaan nilai variabel capital intensity yang diteliti terhadap nilai rata-ratanya sebesar 15,73 persen.

Variabel proporsi komisaris independen memiliki nilai minimum sebesar 0,2000 pada PT. Semen Baturaja Tbk (SMBR) tahun 2017, serta memiliki nilai maksimum sebesar 0,8000 pada PT. Unilever Indonesia Tbk (UNVR) tahun 20132017. Nilai rata-rata variabel proporsi komisaris independen sebesar 0,3923 mempunyai arti bahwa rata-rata total komisaris independen pada perusahaan sampel sebesar 39,23 persen dari total anggota dewan komisaris. Nilai standar deviasi variabel proporsi komisaris independen sebesar 0,1009 menunjukkan bahwa terjadi perbedaan nilai variabel proporsi komisaris independen yang diteliti terhadap nilai rata-ratanya sebesar 10,09 persen.

Uji asumsi klasik yang dilakukan pada penelitian adalah uji normalitas, uji autokorelasi, uji heteroskedatisitas, dan uji multikolinearitas. Hasil uji normalitas menunjukkan nilai Asymp. Sig. (2-tailed) dari kedua persamaan regresi lebih besar dari 0,05 . Hal ini menunjukkan bahwa data penelitian berdistribusi normal. Hasil uji autokorelasi menunjukkan persamaan pertama memiliki nilai Durbin-Watson sebesar 2,036. Hasil uji autokorelasinya adalah dU $<$ DW $<4-$ dU yaitu 1,7887 < $2,036<2,2113$, maka tidak terjadi autokorelasi. Persamaan kedua memiliki nilai 
Durbin-Watson sebesar 1,976. Hasil uji autokorelasinya adalah dU $<$ DW $<4-$ dU yaitu 1,8199 < 1,976 <2,1801, maka tidak terjadi autokorelasi.

Hasil uji heteroskedastisitas menunjukkan nilai signifikasi seluruh variabel bebas pada kedua persamaan regresi lebih besar dari 0,05. Hal ini berarti model regresi penelitian bebas dari gejala heteroskedastisitas. Uji multikolinearitas pada penelitian ini hanya dilakukan pada persamaan regresi linear berganda. Uji multikolinearitas tidak dilakukan pada persamaan MRA karena di dalam persamaan MRA menggunakan interaksi antara variabel bebas dengan variabel moderasi sehingga akan menyebabkan multikolinearitas. Ghozali (2016: 103) menjelaskan bahwa penyebab multikolinearitas adalah adanya efek kombinasi dua atau lebih variabel independen. Hasil uji multikolinearitas menunjukkan bahwa seluruh variabel independen memiliki nilai tolerance lebih besar dari 0,10 atau 10 persen dan nilai VIF lebih kecil dari 10,00. Hal ini berarti tidak terdapat multikolinearitas antar variabel independen.

Analisis regresi linear berganda dilakukan untuk mengetahui pengaruh leverage $\left(\mathrm{X}_{1}\right)$ dan capital intensity $\left(\mathrm{X}_{2}\right)$ pada tax avoidance $(\mathrm{Y})$. Hasil analisis regresi linear berganda dapat dilihat pada Tabel 3.

Tabel 3.

Hasil Analisis Regresi Linear Berganda

\begin{tabular}{|c|c|c|c|c|c|}
\hline \multirow[t]{2}{*}{ Model } & \multicolumn{2}{|c|}{ Unstandardized Coefficients } & \multirow{2}{*}{$\begin{array}{c}\begin{array}{c}\text { Standardized } \\
\text { Coefficients }\end{array} \\
\text { Beta } \\
\end{array}$} & \multirow[t]{2}{*}{$\mathrm{t}$} & \multirow[t]{2}{*}{ Sig. } \\
\hline & $\mathrm{B}$ & Std. Error & & & \\
\hline (Constant) & 0,268 & 0,020 & & 13,584 & 0,000 \\
\hline Leverage $\left(\mathrm{X}_{1}\right)$ & 0,192 & 0,044 & 0,308 & 4,346 & 0,000 \\
\hline Capital Intensity $\left(\mathrm{X}_{2}\right)$ & $-0,177$ & 0,046 & $-0,272$ & $-3,840$ & 0,000 \\
\hline Adjusted $\mathrm{R}_{\text {square }}: 0,106$ & & & & & \\
\hline $\mathrm{F}_{\text {hitung }} \quad: 12,741$ & & & & & \\
\hline Sig. $\mathrm{F}_{\text {hitung }}$ & & & & & \\
\hline
\end{tabular}


Berdasarkan Tabel 3 dapat disusun persamaan regresi sebagai berikut.

$$
\mathrm{Y}=0,268+0,192 \mathrm{X}_{1}-0,177 \mathrm{X}_{2}
$$

Nilai konstanta $(\alpha)$ bernilai positif sebesar 0,268 memiliki arti bahwa apabila variabel leverage dan capital intensity dinyatakan konstan pada angka nol, maka perusahaan cenderung melakukan tindakan tax avoidance.

Koefisien regresi variabel leverage $\left(\beta_{1}\right)$ sebesar 0,192 memiliki arti bahwa apabila leverage meningkat sebesar satu persen, maka tax avoidance akan meningkat sebesar 0,192 persen dengan asumsi variabel bebas lainnya konstan.

Koefisien regresi variabel capital intensity $\left(\beta_{2}\right)$ sebesar $-0,177$ memiliki arti bahwa apabila capital intensity meningkat sebesar satu persen, maka tax avoidance akan menurun sebesar 0,177 persen dengan asumsi variabel bebas lainnya konstan.

Nilai $F_{\text {hitung }}$ yang diperoleh sebesar 12,741 dengan signifikansi 0,000. Nilai signifikansi ini lebih kecil dari $0,05(\mathrm{~F}<\alpha)$ yang berarti bahwa model penelitian ini dinyatakan layak untuk digunakan sebagai model regresi. Hasil ini memberikan makna bahwa variabel leverage dan capital intensity mampu memprediksi atau menjelaskan fenomena tax avoidance pada perusahaan manufaktur yang terdaftar di BEI tahun 2013-2017.

Nilai adjusted $\mathrm{R}^{2}$ yang diperoleh sebesar 0,106 . Ini berarti perubahan yang terjadi pada tax avoidance dapat dijelaskan oleh leverage dan capital intensity sebesar 10,6 persen, sedangkan 89,4 persen sisanya dijelaskan oleh faktor lain yang tidak diuji dalam penelitian ini. 
Variabel leverage $\left(\mathrm{X}_{1}\right)$ memiliki nilai signifikansi t sebesar 0,000 yang lebih kecil dari 0,05 $(\operatorname{Sig}<\alpha)$. Hal ini berarti $\mathrm{H}_{1}$ yang menyatakan bahwa leverage berpengaruh positif diterima. Semakin meningkatnya utang yang digunakan perusahaan untuk membiayai asetnya, maka tindakan tax avoidance perusahaan pun semakin meningkat. Hasil analisis mengkonfirmasi trade-off theory yang menjelaskan bahwa sumber pendanaan keuangan perusahaan yang berasal dari utang dapat memberi manfaat berupa beban bunga sebagai pengurang beban pajak.

Rasio leverage yang meningkat menunjukkan bahwa sumber pendanaan perusahaan yang berasal dari utang yang diberikan oleh pihak ketiga akan semakin tinggi (Nugrahitha dan Suprasto, 2018). Jumlah utang yang meningkat dapat menyebabkan tax avoidance yang dilakukan perusahaan pun meningkat, karena ketika perusahaan menambah jumlah penggunaan utangnya maka beban bunga yang timbul akibat penggunaan utang pun semakin bertambah. Beban bunga merupakan beban yang dapat mengurangi laba sebelum kena pajak perusahaan. Laba sebelum kena pajak yang semakin rendah akan berdampak pada semakin rendahnya beban pajak yang dibayarkan perusahaan. Maka dari itu, leverage yang meningkat menunjukkan bahwa perusahaan cenderung melakukan tindakan tax avoidance dengan memanfaatkan beban bunga yang timbul akibat penggunaan utang untuk mengurangi beban pajak perusahaan. Penelitian ini konsisten dengan penelitian Ariawan dan Setiawan (2017), Rachmitasari (2015) serta Wijayanti dan Lely (2017) yaitu leverage berpengaruh positif pada tax avoidance. 
Variabel capital intensity $\left(\mathrm{X}_{2}\right)$ memiliki nilai signifikansi t sebesar 0,000 yang lebih kecil dari $0,05(\mathrm{Sig}<\alpha)$. Hal ini berarti $\mathrm{H}_{2}$ yang menyatakan bahwa capital intensity berpengaruh positif ditolak. Semakin banyak modal yang diinvestasikan oleh perusahaan dalam bentuk aset tetap, maka tindakan tax avoidance perusahaan semakin menurun. Hasil analisis tidak mengkonfirmasi teori keagenan yang menyatakan bahwa perbedaan kepentingan pemilik saham dan manajemen dapat diatasi dengan memanfaatkan biaya penyusutan yang melekat pada aset tetap. Hal ini disebabkan oleh adanya perbedaan metode penyusutan aset tetap menurut akuntansi dan perpajakan yang dapat menimbulkan koreksi fiskal positif pada akhir periode laporan keuangan (Budianti dan Curry, 2018).

Ketika perusahaan mengestimasi umur manfaat asetnya lebih singkat dibandingkan umur manfaat aset menurut perpajakan, maka beban penyusutan menurut akuntansi akan lebih besar daripada menurut perpajakan sehingga pada akhir periode laporan keuangan akan menimbulkan koreksi fiskal positif. Koreksi fiskal positif akan berdampak pada bertambahnya penghasilan kena pajak dan beban pajak yang dibayarkan perusahaan pun semakin meningkat. Meningkatnya beban pajak yang dibayarkan perusahaan mengindikasikan bahwa tindakan tax avoidance perusahaan semakin rendah. Beban pajak yang meningkat tidak dapat memenuhi keinginan pemegang saham yang mengingkan pembayaran pajak yang rendah, selain itu meningkatnya beban pajak akan mengurangi laba bersih yang diperoleh perusahaan sehingga tidak dapat memenuhi keinginan manajemen yang menginginkan kompensasi yang tinggi. Penelitian ini konsisten dengan penelitian 
Muzakki dan Darsono (2015) serta Budianti dan Curry (2018) yaitu capital intensity berpengaruh negatif pada tax avoidance.

Uji MRA dilakukan untuk mengetahui pengaruh leverage $\left(\mathrm{X}_{1}\right)$ dan capital intensity $\left(\mathrm{X}_{2}\right)$ pada tax avoidance $(\mathrm{Y})$ dengan proporsi komisaris independen sebagai variabel pemoderasi $\left(\mathrm{X}_{3}\right)$. Hasil uji MRA dapat dilihat pada Tabel 4 .

Tabel 4.

Hasil Uji MRA

\begin{tabular}{|c|c|c|c|c|c|}
\hline \multirow[t]{2}{*}{ Model } & \multicolumn{2}{|c|}{$\begin{array}{l}\text { Unstandardized } \\
\text { Coefficients }\end{array}$} & \multirow{2}{*}{$\begin{array}{c}\text { Standardized } \\
\text { Coefficients } \\
\text { Beta } \\
\end{array}$} & \multirow[t]{2}{*}{$\mathrm{t}$} & \multirow[t]{2}{*}{ Sig. } \\
\hline & B & Std. Error & & & \\
\hline (Constant) & 0,349 & 0,084 & & 4,158 & 0,000 \\
\hline Leverage $\left(\mathrm{X}_{1}\right)$ & 0,299 & 0,162 & 0,480 & 1,846 & 0,066 \\
\hline Capital Intensity $\left(\mathrm{X}_{2}\right)$ & $-0,324$ & 0,193 & $-0,497$ & $-1,679$ & 0,095 \\
\hline $\begin{array}{l}\text { Proporsi Komisaris } \\
\text { Independen }\left(\mathrm{X}_{3}\right) \\
\text { Leverage*Proporsi }\end{array}$ & $-0,236$ & 0.210 & $-0,232$ & $-1,123$ & 0,263 \\
\hline $\begin{array}{l}\text { Komisaris Independen } \\
\left(\mathrm{X}_{1} \mathrm{X}_{3}\right)\end{array}$ & $-0,242$ & 0,388 & $-0,219$ & $-0,625$ & 0,533 \\
\hline $\begin{array}{l}\text { Capital Intensity*Proporsi } \\
\text { Komisaris Independen } \\
\left(\mathrm{X}_{2} \mathrm{X}_{3}\right) \\
\text { Adjusted } \mathrm{R}_{\text {square }}: 0,123\end{array}$ & 0,422 & 0,497 & 0,337 & 0,849 & 0,397 \\
\hline $\begin{array}{ll}\mathrm{F}_{\text {hitung }} & : 6,564 \\
\text { Sig. } \mathrm{F}_{\text {hitung }} & : 0,000\end{array}$ & & & & & \\
\hline
\end{tabular}

Berdasarkan Tabel 4 dapat disusun persamaan regresi sebagai berikut.

$$
Y=0,349+0,299 X_{1}-0,324 X_{2}-0,236 X_{3}-0,242 X_{1} X_{3}+0,422 X_{2} X_{3}
$$

Nilai konstanta $(\alpha)$ bernilai positif sebesar 0,349 memiliki arti bahwa apabila variabel leverage, capital intensity, proporsi komisaris independen, interaksi antara leverage dengan proporsi komisaris independen, dan interaksi antara capital intensity dengan proporsi komisaris independen dinyatakan konstan pada angka nol, maka perusahaan cenderung melakukan tindakan tax avoidance.

Koefisien regresi variabel interaksi antara leverage dengan proporsi komisaris independen $\left(\beta_{4}\right)$ sebesar $-0,242$ memiliki arti bahwa apabila interaksi 
antara leverage dengan proporsi komisaris independen meningkat sebesar satu persen, maka tax avoidance tidak mengalami perubahan dengan asumsi variabel bebas lainnya konstan.

Koefisien regresi variabel interaksi antara capital intensity dengan proporsi komisaris independen $\left(\beta_{5}\right)$ sebesar 0,422 memiliki arti bahwa apabila interaksi antara capital intensity dengan proporsi komisaris independen meningkat sebesar satu satuan, maka tax avoidance tidak mengalami perubahan dengan asumsi variabel bebas lainnya konstan.

Variabel moderasi dalam penelitian merupakan jenis variabel moderator homologizer. Hal ini dapat dilihat dari nilai signifikansi yang disajikan pada Tabel 4, dimana variabel proporsi komisaris independen $\left(\beta_{3}\right)$, variabel interaksi antara leverage dengan proporsi komisaris independen $\left(\beta_{4}\right)$, dan variabel interaksi antara capital intensity pada tax avoidance $\left(\beta_{5}\right)$ sama-sama menunjukkan nilai yang tidak signifikan $($ Sig $>\alpha)$. Hal ini menunjukkan bahwa proporsi komisaris independen tidak berpengaruh pada variabel kriterion (tax avoidance) dan tidak berinteraksi dengan variabel prediktor (leverage dan capital intensity). Selain itu, nilai error term pada analisis regresi berganda lebih besar daripada nilai error term pada uji MRA. Nilai error term pada analisis regresi berganda sebesar 0,0970669, sedangkan nilai error term pada uji MRA memiliki nilai yang lebih kecil yaitu sebesar 0,0961346. Semakin kecil nilai error term maka semakin besar tingkat kekuatan hubungan. Hal ini menunjukkan bahwa variabel proporsi komisaris independen memengaruhi kekuatan hubungan yang terlihat dari menurunnya nilai error term. Maka, dapat disimpulkan bahwa proporsi komisaris independen 
dalam penelitian ini merupakan variabel moderator homologizer, karena mampu memengaruhi kekuatan hubungan, namun tidak berinteraksi dengan variabel prediktor $(\mathrm{X})$ dan tidak berhubungan secara signifikan baik dengan prediktor $(\mathrm{X})$ maupun kriterion (Y).

Nilai $F_{\text {hitung }}$ yang diperoleh sebesar 6,564 dengan signifikansi 0,000. Nilai signifikansi ini lebih kecil dari $0,05(\mathrm{~F}<\alpha)$ yang berarti bahwa model penelitian ini dinyatakan layak untuk digunakan sebagai model regresi. Hasil ini memberikan makna bahwa seluruh variabel yaitu leverage, capital intensity, proporsi komisaris independen, interaksi antara leverage dengan proporsi komisaris independen, dan interaksi antara capital intensity dengan proporsi komisaris independen mampu memprediksi atau menjelaskan fenomena tax avoidance pada perusahaan manufaktur yang terdaftar di BEI tahun 2013-2017.

Nilai adjusted $\mathrm{R}^{2}$ yang diperoleh sebesar 0,123 . Ini berarti perubahan yang terjadi pada tax avoidance dapat dijelaskan oleh variabel leverage, capital intensity, proporsi komisaris independen, interaksi antara leverage dengan proporsi komisaris independen, dan interaksi antara capital intensity dengan proporsi komisaris independen sebesar 12,3 persen, sedangkan 87,7 persen sisanya dijelaskan oleh faktor lain yang tidak diuji dalam penelitian ini.

Variabel interaksi antara leverage dengan proporsi komisaris independen memiliki nilai signifikansi t sebesar 0,533 yang lebih besar dari 0,05 ( $\operatorname{Sig}>\alpha)$. Hal ini berarti $\mathrm{H}_{3}$ yang menyatakan bahwa proporsi komisaris independen memperlemah pengaruh leverage pada tax avoidance ditolak. Banyaknya komisaris independen dalam perusahaan tidak memengaruhi tindakan perusahaan 
yang memanfaatkan penggunaan utang sebagai upaya penghindaran pajak. Hasil analisis tidak mengkonfirmasi teori keagenan yang menjelaskan bahwa banyaknya komisaris independen dalam perusahaan dapat melakukan pengawasan yang ketat terhadap keputusan yang diambil perusahaan, termasuk keputusan yang terkait dengan pembayaran pajak.

Ketidaksesuaian hasil analisis dengan hipotesis penelitian dapat ditinjau dari hasil uji statistik deskriptif. Rata-rata perusahaan sampel pada penelitian telah melaksanakan Peraturan Otoritas Jasa Keuangan Republik Indonesia Nomor 33/POJK.04/2014 mengenai jumlah komisaris independen dalam perusahaan sekurang-kurangnya adalah 30 persen. Hal ini dapat dilihat pada hasil uji statistik deskriptif pada Tabel 2 menunjukkan bahwa rata-rata total komisaris independen pada perusahaan sampel sebesar 39,23 persen dari total anggota dewan komisarisnya. Namun, interaksi antara leverage dengan proporsi komisaris independen menunjukkan nilai yang tidak signifikan. Hal ini menunjukkan bahwa banyaknya komisaris independen dalam perusahaan hanya untuk melaksanakan peraturan yang berlaku, sehingga banyaknya komisaris independen dalam perusahaan tidak dapat memengaruhi tindakan perusahaan yang memanfaatkan penggunaan utang sebagai upaya penghindaran pajak.

Secara umum, keputusan pendanaan tidak hanya bergantung pada sifat perusahaan dan lingkungan ekonominya, tetapi juga pada kepribadian manajemen puncak perusahaan (Brealey et al., 2010: 463). Hal ini sejalan dengan theory of planned behavior yang menjelaskan bahwa perilaku manajemen perusahaan terhadap pengambilan keputusan perpajakannya didasarkan atas niat dan 
keinginan manajemen untuk melakukan tindakan yang dianggap menguntungkan (behavioral beliefs). Sehingga, keputusan manajemen perusahaan untuk menggunakan utang sebagai upaya penghindaran pajak sepenuhnya berada di tangan manajemen perusahaan dan tidak dipengaruhi oleh besar kecilnya jumlah komisaris independen dalam perusahaan. Penelitian ini konsisten dengan penelitian Puspita dan Harto (2014) yaitu proporsi komisaris independen tidak berpengaruh pada tax avoidance.

Variabel interaksi antara capital intensity dengan proporsi komisaris independen memiliki nilai signifikansi t sebesar 0,397 yang lebih besar dari 0,05 $\left(\right.$ Sig $>\alpha$ ). Hal ini berarti $\mathrm{H}_{4}$ yang menyatakan bahwa proporsi komisaris independen memperlemah pengaruh capital intensity pada tax avoidance ditolak. Banyaknya komisaris independen dalam perusahaan tidak memengaruhi tindakan perusahaan yang memanfaatkan penggunaan aset tetap sebagai upaya penghindaran pajak. Hasil analisis tidak mengkonfirmasi teori keagenan yang menjelaskan bahwa banyaknya komisaris independen dalam perusahaan dapat meminimalisir perilaku tax avoidance karena meningkatnya pengawasan terhadap kinerja manajemen perusahaan terkait pelaporan beban pajak perusahaan secara wajar.

Apabila dilihat dari hasil uji statistik pada Tabel 2, rata-rata perusahaan sampel pada penelitian ini telah melaksanakan Peraturan Otoritas Jasa Keuangan Republik Indonesia Nomor 33/POJK.04/2014 mengenai jumlah komisaris independen dalam perusahaan sekurang-kurangnya adalah 30 persen. Hal ini ditunjukkan oleh nilai rata-rata total komisaris independen pada perusahaan 
sampel sebesar 39,23 persen dari total anggota dewan komisarisnya. Namun, interaksi antara capital intensity dengan proporsi komisaris independen menunjukkan nilai yang tidak signifikan. Hal ini menunjukkan bahwa banyaknya komisaris independen dalam perusahaan hanya untuk melaksanakan peraturan yang berlaku, sehingga banyaknya jumlah komisaris independen dalam perusahaan tidak dapat memengaruhi tindakan perusahaan yang memanfaatkan penggunaan aset tetap sebagai upaya penghindaran pajak.

Hasil analisis sejalan dengan theory of planned behavior yang menjelaskan perilaku manajemen perusahaan yang hanya sekedar memenuhi peraturan yang ada terkait jumlah komisaris independen dalam perusahaan (normative beliefs), sehingga komisaris independen kurang efektif dalam melaksanakan fungsi pengawasannya. Mulyani dkk (2018) mengemukakan bahwa kurang efektifnya fungsi pengawasan komisaris independen terhadap manajemen dalam melakukan tax avoidance akan terbatas apabila pihak-pihak terafiliasi yang ada di perusahaan lebih mendominasi dan dapat mengendalikan dewan komisaris independen, sehingga komisaris independen kurang tanggap dalam memperhatikan ada atau tidaknya tax avoidance perusahaan. Maka dari itu, banyaknya komisaris independen dalam perusahaan tidak mampu meminimalisir perilaku tax avoidance perusahaan yang memanfaatkan penggunaan aset tetap sebagai upaya penghindaran pajak, karena kontrol yang dimiliki komisaris independen masih didominasi oleh pihak yang terafiliasi dengan perusahaan. Penelitian ini konsisten dengan penelitian Dewi dan Sari (2015) yaitu proporsi komisaris independen tidak berpengaruh pada tax avoidance. 
Implikasi teoretis penelitian adalah mengkonfirmasi trade-off theory yang menjelaskan bahwa penggunaan utang sebagai sumber pendanaan keuangan perusahaan dapat memberi manfaat berupa beban bunga sebagai pengurang beban pajak. Implikasi praktis penelitian adalah memberikan informasi bagi para investor di pasar modal agar dalam mengambil keputusan investasi memperhatikan tindakan tax avoidance perusahaan, karena tax avoidance dapat berpengaruh pada laba yang diperoleh perusahaan sehingga berdampak pada dividen yang akan diterima oleh pemegang saham.

\section{SIMPULAN}

Berdasarkan pembahasan hasil penelitian, maka dapat disimpulkan bahwa leverage berpangaruh positif pada tax avoidance. Hal ini berarti semakin tinggi tingkat utang yang digunakan perusahaan dalam membiayai asetnya maka semakin tinggi tingkat penghindaran pajaknya. Capital intensity berpengaruh negatif pada tax avoidance. Hal ini berarti semakin banyak modal yang diinvestasikan perusahaan dalam bentuk aset tetap maka semakin rendah tingkat penghindaran pajaknya. Proporsi komisaris independen tidak memoderasi pengaruh leverage pada tax avoidance. Hal ini berarti banyaknya komisaris independen dalam perusahaan tidak memengaruhi tindakan perusahaan yang memanfaatkan penggunaan utang sebagai upaya penghindaran pajak. Proporsi komisaris independen tidak memoderasi pengaruh capital intensity pada tax avoidance. Hal ini berarti banyaknya komisaris independen dalam perusahaan 
tidak memengaruhi tindakan perusahaan yang memanfaatkan penggunaan aset tetap sebagai upaya penghindaran pajak.

Saran yang dapat diberikan untuk peneliti selanjutnya adalah disarankan untuk menambah beberapa variabel lain seperti corporate risk (Dewi dan Sari, 2015), karakter eksekutif (Nugrahitha dan Suprasto, 2018), dan kepemilikan institusional (Yogiswari dan Ramantha, 2017) yang dapat memengaruhi tax avoidance karena nilai adjusted $\mathrm{R}^{2}$ penelitian yang relatif kecil yaitu 0,123 atau 12,3 persen. Selain itu, peneliti selanjutnya juga dapat melakukan penelitian serupa dengan mengambil sektor perusahaan yang berbeda di Bursa Efek Indonesia (BEI). Bagi pemerintah diharapkan lebih memperketat pengawasan terhadap perusahaan-perusahaan yang melaporkan kewajiban perpajakannya, khususnya bagi perusahaan yang memiliki utang yang besar. Bagi perusahaan diharapkan mampu menerapkan mekanisme corporate governance dengan baik agar mampu mengawasi serta mengontrol kebijakan yang diambil perusahaan agar tidak melanggar peraturan yang berlaku.

\section{REFERENSI}

Andhari, P. A. S., \& Sukartha, I. M. (2017). Pengaruh Pengungkapan Corporate Social Responsibility, Profitabilitas, Inventory Intensity, Capital Intensity, dan Leverage pada Agresivitas Pajak. E-Jurnal Akuntansi Universitas Udayana, 18(3), 2115-2142.

Anindyka, D., Pratomo, D., \& Kurnia. (2018). Pengaruh Leverage (DAR), Capital Intensity, dan Inventory Intensity Terhadap Tax Avoidance. E-Proceeding of Management, 5(1), 713-719. 
Annisa. (2017). Pengaruh Return on Asset, Leverage, Ukuran Perusahaan dan Koneksi Politik Terhadap Penghindaran Pajak. JOM Fekon, 4(1), 1-15.

Arianandini, P. W., \& Ramantha, I. W. (2018). Pengaruh Profitabilitas, Leverage, dan Kepemilikan Institusional pada Tax Avoidance. E-Jurnal Akuntansi Universitas Udayana, 22(3), 2088-2116.

Ariawan, I. M. A. R., \& Setiawan, P. E. (2017). Pengaruh Dewan Komisaris Independen, Kepemilikan Institusional, Profitabilitas, dan Leverage Terhadap Tax Avoidance. E-Jurnal Akuntansi Universitas Udayana, 18(3), 1831-1859.

Asri, I. A. T. Y., \& Suardana, K. A. (2016). Pengaruh Proporsi Komisaris Independen, Komite Audit, Preferensi Risiko Eksekutif dan Ukuran Perusahaan pada Penghindaran Pajak. E-Jurnal Akuntansi Universitas Udayana, 16(1), 72-100.

Brealey, Myers, \& Allen. (2010). Principles of Corporate Finance Tenth Edition. New York: McGraw-Hill.

Budianti, S., \& Curry, K. (2018). Pengaruh Profitabilitas, Likuiditas, dan Capital Intensity Terhadap Penghindaran Pajak (Tax Avoidance). Prosiding Seminar Nasional Cendekiawan 4. Jakarta.

Cahyanti, I. S., Muhsin, \& Suharto, A. B. (2017). Profitabilitas, Leverage, Likuiditas, dan Tax Avoidance Kasus: Perusahaan Pertambangan yang Terdaftar di Jakarta Islamic Index. Jurnal EKUBIS, 2(1), 159-171.

Comanor, W. S., \& Wilson, T. A. (1967). Advertising Market Structure and Performance. The Review of Economics and Statistics, 49(4), 423-440.

Darmawan, I. G. H., \& Sukartha, I. M. (2014). Pengaruh Penerapan Corporate Governance, Leverage, Return on Assets, dan Ukuran Perusahaan pada Penghindaran Pajak. E-Jurnal Akuntansi Universitas Udayana, 9(1), 143161.

Delgado, F. J., Rodriguez, E. F., \& Arias, A. M. (2014). Effective Tax Rates in Corporate Taxation: a Quantile Regression for the EU. Inzerine Ekonomia 
Engineering Economics, 25(5), 487-496.

Dewi, G. A. P., \& Sari, M. M. R. (2015). Pengaruh Insentif Eksekutif, Corporate Risk, dan Corporate Governance pada Tax Avoidance. E-Jurnal Akuntansi Udayana, 13(1), 50-67.

Dewi, N. L. P. P., \& Noviari, N. (2017). Pengaruh Ukuran Perusahaan, Leverage, Profitabilitas, dan Corporate Social Responsibility Terhadap Penghindaran Pajak (Tax Avoidance). E-Jurnal Akuntansi Universitas Udayana, 21(1), 830-859.

Dharma, I. M. S., \& Ardiana, P. A. (2016). Pengaruh Leverage, Intensitas Aset Tetap, Ukuran Perusahaan, dan Koneksi Politik Terhadap Tax Avoidance. EJurnal Akuntansi Universitas Udayana, 15(1), 584-613.

Dharma, N. B. S., \& Noviari, N. (2017). Pengaruh Corporate Social Responsibility dan Capital Intensity Terhadap Tax Avoidance. E-Jurnal Akuntansi Universitas Udayana, 18(1), 529-556.

Diantari, P. R., \& Ulupui, I. A. (2016). Pengaruh Komite Audit, Proporsi Komisaris Independen, dan Proporsi Kepemilikan Institusional Terhadap Tax Avoidance. E-Jurnal Akuntansi Universitas Udayana, 22(4), 1-31.

Ghozali, I. (2016). Aplikasi Analisis Multivariate dengan Program IBM SPSS 23. Semarang: Badan Penerbit Universitas Diponegoro.

Gupta, S., \& Newberry, K. (1997). Determinants of the Variability of Corporate Effective Tax Rates: Evidence from Longitudinal Data. Journal of Accounting and Public Policy, 16(1), 1-34.

Hackbarth, D., \& Zhou, B. (2018). Effects of New Tax Law on Capital Structure and Cost of Capital. Tax Notes, 158(11), 1522-1528.

Hanlon, M., \& Heitzman, S. (2010). A Review of Tax Research. Journal of Accounting and Economics, 50(40), 127-178. 
Hartadinata, O. S., \& Tjaraka, H. (2013). Analisis Pengaruh Kepemilikan Manajerial, Kebijakan Hutang, dan Ukuran Perusahaan Terhadap Tax Aggressiveness pada Perusahaan Manufaktur di Bursa Efek Indonesia 20082010. Jurnal Ekonomi dan Bisnis, (3), 48-59.

Irianto, B. S., Sudibyo, Y. A., \& Wafirli, A. (2017). The Influence of Profitability, Leverage, Firm Size and Capital Intensity Towards Tax Avoidance. International Journal of Accounting and Taxation, 5(2), 33-41.

Jacob, F. O. F. (2014). An Empirical Study of Tax Evasion and Tax Avoidance: A Critical Issue in Nigeria Economic Development. Journal of Economics and Sustainable Development, 5(18), 22-27.

Jensen, M. C., \& Meckling, W. H. (1976). Theory of the Firm: Managerial Behavior, Agency Costs and Ownership Structure. Journal of Financial Economics, 3(4), 305-360.

Jingga, V., \& Lina. (2017). Factors Influencing Tax Avoidance Activity: An Empirical Study from Indonesia Stock Exchange. Indian Pacific Journal of Accounting and Finance (IPJAF), 1(1), 17-25.

Lestari, G. A. W., \& Putri, I. G. A. . A. D. (2017). Pengaruh Corporate Governance, Koneksi Politik, dan Leverage Terhadap Penghindaran Pajak. E-Jurnal Akuntansi Universitas Udayana, 18(3), 2028-2054.

Maharani, I. G. A. C., \& Suardana, K. A. (2014). Pengaruh Corporate Governance, Profitabilitas dan Karakteristik Eksekutif pada Tax Avoidance Perusahaan Manufaktur. E-Jurnal Akuntansi Universitas Udayana, 9(2), 525-539.

Minnick, K., \& Noga, T. (2010). Do Corporate Governance Characteristics Influence Tax Management?. Journal of Corporate Finance, 16, 703-718.

Mulyani, S., Darminto, \& N. P, M. G. W. E. (2014). Pengaruh Karakteristik Perusahaan, Koneksi Politik dan Reformasi Perpajakan Terhadap Penghindaran Pajak (Studi pada Perusahaan Manufaktur yang Terdaftar di Bursa Efek Tahun 2008-2012). Jurnal Mahasiswa Perpajakan Universitas Brawijaya, 1(2), 1-9.

Mulyani, S., Wijayanti, A., \& Masitoh, E. (2018). Pengaruh Corporate Governance Terhadap Tax Avoidance (Perusahaan Pertambangan yang 
Terdaftar di BEI). Jurnal Riset Akuntansi dan Bisnis Airlangga, 3(1), 322340.

Murni, Y., Sudarmaji, E., \& Sugihyanti, E. (2016). The Role of Institutional Ownerships , Board of Independent Commissioner and Leverage: Corporate Tax Avoidance in Indonesia. IOSR Journal of Business and Management (IOSR-JBM), 18(11), 79-85.

Muzakki, M. R., \& Darsono. (2015). Pengaruh Corporate Social Responsibility dan Capital Intensity Terhadap Penghindaran Pajak. Diponegoro Journal of Accounting, 4(3), 1-8.

Nugrahitha, I. M. A., \& Suprasto, H. B. (2018). Pengaruh Profitabilitas, Leverage, Corporate Governance, dan Karakter Eksekutif pada Tax Avoidance. EJurnal Akuntansi Universitas Udayana, 22(3), 2016-2039.

Otoritas Jasa Keuangan. Peraturan Otoritas Jasa Keuangan Republik Indonesia Nomor 33/POJK.04/2014 Tentang Direksi dan Dewan Komisaris Emiten atau Perusahaan Publik. (2014). Indonesia.

Park, S. (2018). Related Party Transactions and Tax Avoidance of Business Groups. Sustainability, 10(10), 1-14.

Pemerintah Republik Indonesia. Undang-Undang Republik Indonesia Nomor 36 Tahun 2008 Tentang Pajak Penghasilan. (2008). Indonesia.

Praditasari, N. K. A., \& Setiawan, P. E. (2017). Pengaruh Good Corporate Governance, Ukuran Perusahaan, Leverage dan Profitabilitas pada Tax Avoidance. E-Jurnal Akuntansi Universitas Udayana, 19(2), 1229-1258.

Puspita, S. R., \& Harto, P. (2014). Pengaruh Tata Kelola Perusahaan Terhadap Penghindaran Pajak. Diponegoro Journal Of Accounting, 3(2), 1-13.

Rachmitasari, A. F. (2015). Pengaruh Return on Assets, Leverage, Corporate Governance, Ukuran Perusahaan dan Kompensasi Rugi Fiskal pada Tax Avoidance. Naskah Publikasi. Universitas Muhammadiyah Surakarta. 
Reminda, A. D. (2017). Pengaruh Corporate Social Responsibility, Profitabilitas, Ukuran Perusahaan, dan Capital Intensity Terhadap Agresivitas Pajak. JOM Fekon, 4(2), 4279-4293.

Rodriguez, E. fernandez, \& Arias, A. M. (2012). Do Business Characteristics Determine an Effective Tax Rate?. Chinese Economy, 45(6), 60-83.

Salaudeen, Y. M. (2017). Corporate Effective Tax Rates in the Financial Services Sector: Evidence from Nigeria. International Journal of Accounting and Taxation, 5(1), 68-88.

Wiguna, I. P. P., \& Jati, I. K. (2017). Pengaruh Corporate Social Responsibility, Preferensi Risiko Eksekutif, dan Capital Intensity pada Penghindaran Pajak. E-Jurnal Akuntansi Universitas Udayana, 21(1), 418-446.

Wijayanti, Y. C., \& Lely, N. K. (2017). Pengaruh Proporsi Komisaris Independen, Kepemilikan Institusional, Leverage, dan Ukuran Perusahaan pada Penghindaran Pajak. E-Jurnal Akuntansi Universitas Udayana, 20(1), 699728.

Yogiswari, N. K. K., \& Ramantha, I. W. (2017). Pengaruh Likuiditas dan Corporate Social Responsibility pada Agresivitas Pajak dengan Corporate Governace sebagai Variabel Pemoderasi. E-Journal Akuntansi Universitas Udayana, 21(1), 730-759.

Zemzem, A., \& Ftouhi, K. (2013). The Effects of Board of Directors' Characteristics on Tax Aggressiveness. Research Journal of Finance and Accounting, 4(4), 2222-2847.

Zhou, Y. (2011). Ownership Structure, Board Characteristics, and Tax Aggressiveness. Master Degree Dissertation. Lignan University. 